\title{
AZ ÖNELFOGADÁS KIHÍVÁSAITÓL A TESTPOZITÍV MOZGALMAKIG - A POZITÍV PSZICHOLÓGIA TESTKÉPEI
}

\author{
CSABAI MÁRTA \\ Szegedi Tudományegyetem Pszichológiai Intézet \\ E-mail: marta.csabai@psy.u-szeged.hu \\ Beérkezett: 2019. október 15. - Elfogadva: 2019. október 16.
}

\begin{abstract}
Bár a testkép az énképpel együtt az önmagunkhoz és a világhoz való viszony alapvetô összetevője, a témával kapcsolatos korábbi kutatások elsốsorban a negatív testképre fókuszáltak. A pozitív pszichológiában is viszonylagos késéssel jelent meg a pozitív testkép mint önálló koncepció. Az utóbbi évek kutatásai bebizonyitották, hogy a pozitív testkép nem a negatív testkép tükörképe, hanem önálló dimenzió, amely összefüggésben van számos, a szubjektív jóllétet, illetve az általános pozitív orientációt befolyásoló tényezốvel. Ezek között kiemelkedô szerepet tölt be az önelfogadás. A tanulmány összefoglalja a pozitív testkép koncepciójának nemzetközi fejlódését, és bemutatja, hogy a pozitív és a negatív testkép viszonyában miként reprezentálódik az a pozitív pszichológiai alaptétel, hogy a well-being dimenzió önálló tartalmakkal rendelkezik, és nem csupán a diszfunkció és a negatív tartalmak hiányát jelenti. Különösen élesen világítja meg a pozitív testkép konstrukció összetevôivel, illetve az egyéni kontrollal és autonómiával való kapcsolat kérdéseit és erôsödô dilemmáit a testpozitív mozgalom. A testpozitív mozgalom mint esetpélda alkalmas arra is, hogy általa végiggondoljuk a pozitív pszichológia néhány fontos kortárs kihívását mind az elméletalkotás, mind a gyakorlat szempontjából.
\end{abstract}

Kulcsszavak: pozitív testkép, önelfogadás, szubjektív jóllét, testpozitív mozgalom 
Evidenciának gondoljuk, hogy a testünkhöz való viszony elválaszthatatlan része a szubjektív jóllétünknek. Az, hogy miként kezeljük, hogyan mozgatjuk, tápláljuk, öltöztetjük, díszítjük a testünket, és milyen a vele való kapcsolatunk, egyaránt befolyással van a jóllét különböző összetevőire. Ennek ellenére a kutatások egészen az utóbbi idôkig keveset foglalkoztak ezekkel az összefüggésekkel. A pozitív pszichológia meghatározó szakértôk (így például Oláh, 2019) által legígéretesebbnek tartott kortárs elmélete, Caprara (2019) pozitív orientáció teóriája fontos összetevójének tartja az énhez való pozitív viszonyulást, de ennek testi vonatkozásait nem emelte ki külön. Az alábbiakban azt járjuk körül, hogy a testkép, mely az énképpel együtt elválaszthatatlan összetevôje az énhez való viszonynak, miként jelent meg, és milyen helyet foglal el a pozitív pszichológiai elméletalkotásban és gyakorlatban.

\section{A TESTKÉP ÉS A SZUBJEKTÍV JÓLLÉT KAPCSOLATA A PSZICHOLÓGIÁBAN}

Bár a test problémája az utóbbi évtizedekben megjelent a társadalomtudományokban, az elméletalkotás és az empirikus kutatások elsôsorban arra fókuszáltak, hogy milyen feszültségeket, tüneteket okoznak a testben való létezés számára a megjelenéssel kapcsolatos viták, az öregedéstôl való félelem és az ehhez kapcsolódó technikák, az egészségkultusz ellentmondásai, illetve mindezek meghatározottsága a fogyasztói társadalom, a globalizált médiakultúra és a társadalom mint általános környezet által. Ennek kapcsán került fókuszba az a kérdés is, hogy a test által küldött üzenetek - tudatos és tudattalan jelzések - mennyire tudják hatékonyan és pontosan kifejezni (vagy épp elrejteni) a szubjektív, belsôleg megélt identitásélményeket, az egyén érzelmi állapotát, a különbözô környezeti és társas elvárások által artikulált szerepeket (Csabai és Erôs, 2000).

A testkép mint önálló pszichológiai konstrukció kutatása hosszabb múltra tekint vissza, mint a test általános témájának bekerülése a társadalomtudományokba. A pszichológiai testképkutatások legfóbb kiindulópontja az volt, hogy a stabil testkép feltétele annak, hogy az egyén pontos képpel rendelkezzen másokhoz való viszonyáról, el tudja különíteni a test külsô és belsố viszonylatait, az aktív és passzív pozíciókat, és meg tudja határozni önmagát mint önálló szubjektumot (Schilder, 1935). Az alapvetô elméleti koncepciók kidolgozása után megjelentek a testkép egészséggel és pszichológiai állapottal való összefüggéseire irányuló vizsgálatok is. Mivel azonban a pozitív pszichológiai szemlélet csupán az utóbbi évtizedekben erôsödött meg, a szakemberek hagyományosan nem a szubjektív jóllét mutatóival való kapcsolatokat keresték, hanem elsôsorban arra koncentráltak, hogy megértsék a (negatív) testkép és a diszfunkcionális viselkedés, vagy a betegségek közötti kapcsolatot (Tylka, 2011). Megállapították, hogy a személy által negatívan értékelt és kevésbé elfogadott, vagy egyenesen elutasított testkép - melyet a szakirodalom átfogóan a „negatív testkép” fogalmával ír le - összefügg az evészavarokkal, a depresszióval, a negatív érzelmekkel, a társas szorongással, a bizalomhiánnyal, a rizikóviselkedéssel; összességében tehát a pszichológiai jóllét alacsonyabb szintjével (Avalos, Tylka és Wood-Barcalow, 2005). A negatív testkép hangsúlya (a pozitívval szemben) betudható annak is, hogy több meghatározó szerzố hangsúlyozta, korunkban növekszik a testtel kapcsolatos elidegenedés, indifferencia (Frank, 1998), illetve erósödik a szorongás és a negatív kapcsolat a test és az én 
között (Orbach, 2009). Valójában mindezek egyik következménye a negatív testkép erôsödése, mely többek között a testmódosítási technikák, kozmetikai mútétek növekedésében, vagy például az önsértô viselkedésformák számának emelkedésében mutatkozik meg (Favazza, 2011).

Évtizedeken keresztül a fenti bizonyítékokra és összefüggésekre épültek a (negatív) testképpel kapcsolatos intervenciók is, de egyre inkább szembe kellett nézni azzal, hogy a testképterápiák elsôsorban a negatív testkép csökkentésében hatásosak, és nem segítik megfelelően a pozitív testkép erôsödését, hanem inkább csak a problémamentes, „semleges” testkép elérését szolgálják. Ez látszólag pozitív eredmény is lehetne, azonban egyre több bizonyíték szól amellett, hogy nem létezik a testhez való semleges viszony, mert éppen ez lehet az egyik kiindulópontja annak az elidegenedett állapotnak, amely kitermeli a testtel kapcsolatos szorongásokat és a diszfunkcionális, öndestruktív viselkedésformákat (Frank, 1998). A negatív testkép csökkentését, „semlegesítését” célzó intervenciók másik káros következménye lehet, hogy „elaltatják” a személy figyelmét a testével kapcsolatban, csökkentve az öngondoskodást, a testtel való törôdést, az egészségmegórzési motivációt, illetve a tünetek, diszfunkcionális jelzések észlelését (Hefferon, 2015). Ezért nagyon fontos, hogy a pszichológia ne csak a testkép hagyományosan elemzett, kognitív tartalmait, hanem a szubjektív tapasztalatot, a megélt test folyamatait és élményeit is vizsgálni tudja. Ehhez nyújt keretet az „embodiment” (magyarra nehezen fordítható, „testben létezés”), fogalma, mely a testi tapasztalatokkal kapcsolatos tudatosság és válaszkészség jelenségével foglalkozik (Piran és Teall, 2012). Kiemelt szerepet tölt be ezen tényezók között a testtudatosság, mely jelentôsen befolyásolja az egyén helyzetekkel kapcsolatos percepcióit és ítéleteit, továbbá azt, hogy pontosan és biztonságosan tudjon kapcsolódni a saját testi érzéseihez és érzelmeihez. Ehhez kapcsolódik a test pozitív megélésének egyik alappillére, az érintés megfelelô észlelése és fogadása, ami bizonyítottan hozzájárul a szubjektív jóllét érzéséhez, olyan fiziológiai folyamatok által is, mint a kortizolszint és a vérnyomás csökkenése, a szerotonin-, dopamin- és oxytocinszintek növekedése (Hefferon, 2015). A kutatások további pozitív összefüggéseket találtak a testtudatosság dimenziója és a szubjektív jóllét között, ami ismételten megerôsíti, hogy a test témájának még fontosabb szerepet kell kapnia a pozitív pszichológia paradigmájában (Hefferon, 2013). A gyakorlat szempontjából ez azt is jelenti, hogy a testképzavarok tüneteinek kezelése mellett fokozatosan a figyelem középpontjába kerül a test értékelése, tisztelete és megbecsülése is, aminek számos pozitív hatása lehet az egészségre és a pszichológiai jóllétre. Ezeket az összefüggéseket azonban jól megalapozott elméletekkel és körültekintô empirikus bizonyítékokkal kell alátámasztani.

\section{A POZITÍV TESTKÉP KONCEPCIÓJA}

Bár a pozitív pszichológia szemléleti keretei és alapfogalmai már az 1990-es évektôl rendelkezésre álltak, a pozitív testkép és a jóllét összefüggéseinek kutatása némi késéssel, a 2000-es évek elején indult meg. Elsôsorban Thomas Cash fôszerkesztố munkájának köszönhetôen, a 2004-ben alapított Body Image címú folyóirat lett az a tudományos fórum, ahol elsôként kapott nagyobb nyilvánosságot ez a téma. A folyóirat alapvetốn 
három fố célt tüzött ki: 1. a pozitív testkép kialakulását befolyásoló tényezôk vizsgálatát, 2. az adaptív testképfolyamatok és ezek klinikailag releváns konzekvenciáinak feltárását a pszichés múködés és az életminôség szempontjából, illetve 3. a pozitív testképet elősegítô intervenciók fejlesztését és bemutatását (Cash, 2004).

Mérföldkônek számított a téma kutatásának történetében, amikor Williams, Cash és Santos (2004) közölték az elsố tanulmányt, melyben igazolták, hogy a pozitív testkép egy önálló és egységes koncepció. Ennek elôzménye volt Cash és Fleming (2002) tanulmánya, melyben elôször írták le fiatal nôk körében, hogy a testkép pozitív hatással van számos életterületre, melyek közül a szerzók tizenkilencet vizsgáltak. Ez azért volt újszerú és meghatározó eredmény, mert korábban az a dogma élt a szakmai köztudatban, hogy a testkép a fiatal nốknél inkább negatív hatást fejt ki a viselkedés és az életminôség szempontjából. Egy késôbbi tanulmányban viszont azt állapították meg, hogy a testképpel kapcsolatos életminôség magasabb szintje jellemzi a férfiakat, az afrikai amerikai nóket (szemben a fehérekkel) és az alacsonyabb testtömegindexszel rendelkezóket (Cash, Jakadtar és Williams, 2004). A pozitív testképpel kapcsolatos elsố kutatásokkal azonos időben intervenciós fejlesztések is megjelentek. Ezek között kiemelendô Cash 8 lépcsôs kognitív viselkedésterápiás programja, ahol a résztvevôk a testükhöz való pozitív viszonyulást, a testrôl való pozitív beszédet és az önprezentációt gyakorolják (Cash, 2008).

Szintén ebben az idôszakban született az azóta legszélesebb körben használt mérôeszköz, a Testértékelési Skála (Body Appreciation Scale, BAS; Avalos és mtsai, 2005). Ennek magyar adaptációja 2013-ban jelent meg (Béres, Czeglédi és Babusa, 2013), mely a közelmúltban egy szintén magyar fejlesztésú Testbecsülési kérdő̂́v alapjaként is szolgált (Obál, Hamvai és Pikó, 2019). Az eredeti kérdőív BAS-2 néven ismert újabb nemzetközi változata kifejezetten azzal a céllal készült, hogy a) a testtel kapcsolatos kedvezô véleményt mérje, függetlenül a fizikai megjelenéstôl, b) feltárja a test elfogadásának a mértékét a médiaideáloktól függetlenül, továbbá hogy c) képet alkosson a test tiszteletérôl, szükségleteirôl és az egészségvédô magatartásról, illetve d) a test védelmérôl az irreális szépségideálokkal szemben (Tylka és Wood-Barcalow, 2015b).

A 2000-es évek elsô évtizedének fentiekben bemutatott fejlesztései után 2010-ben született meg a pozitív testkép legáltalánosabban használt definíciója: „A pozitív testkép átfogó szeretet és tisztelet a test iránt, amely lehetồvé teszi az egyének számára, hogy (a) értékeljék testük egyedi szépségét és müködését, mely óket szolgálja, (b) elfogadják, sôt akár csodálják is a testüket, azon tulajdonságaival együtt is, melyek nem igazodnak az idealizált képekhez, (c) szépnek, kellemesnek és magabiztosnak érezzék a testüket és legyenek vele boldogok, ami kifelé gyakran egyfajta sugárzásban jelenik meg, (d) a testük erényeit hangsúlyozzák és ne a tökéletlenségét, és végül $(f)$ a bejövố információt a test védelme szerint értékeljék, azaz a pozitív információt internalizálják, a negativat pedig utasitsák el, vagy keretezzék át." (Wood-Barcalow, Tylka és Augustus-Horvath, 2010, 112.)

Kérdés, hogy mindez mennyire általánosítható különböző szociodemográfiai csoportokra és kultúrákra, ugyanis a szerzôk is elismerik, hogy a definíció csupán egyetemistákkal és testszakértôkkel való kutatás és konzultáció alapján készült. A Testértékelési skálával mérve a test elfogadása és tisztelete kiemelkedố faktor a nyugati és a nem nyugati populációknál is. Azonban a keleti mintákon (Malájzia, Indonézia, Brazília és 
Korea) erôs tényezô a test feletti autonómia és a testbe való befektetés fontossága is a test pozitív értékelésében (Swami és Jaafar, 2012, Swami, Kanaan és Furnham, 2012). Ezt a kulturális különbséget sok egyéb szemponttal együtt még tovább kell vizsgálni.

A pozitív testkép összetevôinek vizsgálata serdülô fiúk és lányok testképének a kutatásával kezdôdött, és hasonlóképp lányokkal és nôkkel készült interjúk képezték az alapját Piran fejlôdési, embodimentmodelljének (Piran és Teall, 2012), melyben a pozitív testkép alapját a test-szelf integrációban látták, ahol az egyén „egynek érzi magát a testével”. Ez az állapot magában foglalja a kompetencia érzését és azt, hogy az egyéniség szabadon kifejezhetô a test által, illetve hogy a szociokulturális kihívások szabadon megkérdôjelezhetôk. A modell a szelf vágyaival és szükségleteivel való kapcsolatot is figyelembe veszi, ahogy a mások vágyaival való kapcsolatot is. Észrevehetjük, hogy nagy az átfedés a pozitív testkép és az embodiment koncepciói között, ami részben erôsíti a pozitív testkép konstrukció fenomenológiai alapjait, azonban felhívja a figyelmet arra is, hogy tovább kell pontosítani a fogalmakat, és alaposabban megvizsgálni a konstrukciók közötti átfedéseket és különbségeket (Menzel és Levine, 2011).

Mivel gyakoriak az ezzel kapcsolatos félreértések, fontos hangsúlyozni, hogy a pozitív testkép nem a testtel való elégedetlenség hiányát jelenti, hanem önálló pozitív viszonyulásokat, értékeléseket és érzelmeket. Ezt igazolja például, hogy a pozitív testkép erôsödik az életkorral, míg a testtel való elégedetlenség független az életkortól (Tiggemann és McCourt, 2013). A pozitív testkép többdimenziós, komplex konstrukció, tehát nem csak azt jelenti, hogy valaki elégedett-e a testével. Menzel és Levine (2011) a pozitív testkép három fó komponensét határozta meg: 1. a test megjelenésének és múködésének értékelése; 2. a test tapasztalataival és szükségleteivel kapcsolatos tudatosság és figyelem, 3. pozitív kognitív stílus létrehozása a testtel kapcsolatos üzenetek feldolgozására, a test védelmét szem eloótt tartva.

\section{A POZITÍV ÉS A NEGATÍV TESTKÉP}

Egyre több tudományos bizonyíték szól amellett, hogy a pozitív és a negatív testkép független konstrukciók, azaz egymástól elkülönülten fejtik ki a hatásukat a kimeneti változókra (Tylka és Wood-Barcalow, 2015a; Gillen, 2015). Ez azt jelenti, hogy a szakmai és laikus közvélekedéssel ellentétben nem egy kontinuumon helyezkednek el, és nem egymás ellentétei. Tehát nem helytálló az az összefüggés, hogy „ha a negatív testkép alacsony, akkor a pozitív testkép magas”. Ezt igazolta például Williams, Cash és Santos (2004) vizsgálata, melyben három csoportot különítettek el: pozitív testképpel rendelkezôk $(54 \%)$, negatív testképpel bíró személyek (23\%) és az egyik csoportba sem sorolható, de a testükkel elégedetlen személyek (23\%). A két utóbbi csoportnak hasonló volt a testével való elégedetlensége, azonban az a csoport, ahol maga a testkép is negatív volt, nagyobb érzelmi distresszt élt át, a testkép negatívabb hatást gyakorolt az életminôségre. A pozitív testképú csoport életminôsége jobb volt, és úgy érezték, hogy a testképük jó hatással van az életükre. Egyszerúen fogalmazva, ebból az következik, hogy a pozitív és negatív testkép egyik különbsége, hogy a pozitív testkép esetén a személy elfogadja a testét - miközben korántsem biztos, hogy minden testi tulajdon- 
ságával elégedett. A negatív testkép esetén nem fogadja el a testét olyannak, amilyen. Tehát nem az adja a különbséget a pozitív és negatív testkép között, hogy a személy mennyire elégedett magával, hanem hogy mennyire fogadja el a testét.

Általában erôs vagy közepes negatív kapcsolatot találnak a pozitív és negatív testkép között, tehát ez azt is jelenthetné, hogy tükörfogalmak. Azonban mégis több bizonyíték szól amellett, hogy elkülönült konstrukciók. Ezt az is jelzi, hogy más változókkal egyedi, eltérố kapcsolatban vannak (Gillen, 2015). Például a testértékelés pozitívan korrelál az elônyös külsô értékeléssel és a test megbecsülésével, de negatívan korrelál a testtel való elégedetlenséggel, a test ellenôrzésével és a testtel kapcsolatos szégyennel mind a nôk, mind a férfiak esetében. Már a korai vizsgálatokban kimutatták, hogy például a fiatal nóknél az elégedetlenség kapcsolatban van a negatív affektivitással, de a testértékelés nem függ össze a depresszióval a kötôdés és a perfekcionizmus kontrollálása után (Stice, 2001). Azonban ezek az összefüggések tovább vizsgálandók, mert többen felvetik, hogy lehetséges, hogy az eltérések hátterében mérési és módszertani okok állnak (Halliwell, 2015).

A pozitív testkép vagy közvetlenül, vagy pedig közvetve, így például a káros társas hatások kerülése által kapcsolódik a viselkedéshez, az életminôséghez, a jólléthez és a pszichés állapothoz. Ebbôl adódóan azok az intervenciók, amelyek külön-külön veszik figyelembe a pozitív és negatív testképet mint dimenziót, holisztikusabb megközelítést ajánlanak az egészség és a jóllét optimalizálására, mint azok, amelyek csupán a testkép mint általános konstruktum értékét, jellemzôit vagy az ahhoz való viszonyt vizsgálják.

A mentális egészséget tekintve egyre több a bizonyíték azzal kapcsolatban, hogy a pozitív testkép közvetlen kapcsolatban áll egy sor olyan mutatóval, mint az optimizmus, a pozitív érzelmek, az öntisztelet, az élettel való elégedettség és a boldogság. Számos tanulmány bizonyította azt is, hogy a pozitív testkép összefügg a pozitív énképpel és a magasabb önbecsüléssel (Gillen, 2015; Tylka és Wood-Barcalow, 2015b). Azonban bizonyos tényezók korlátozhatják is a testkép és a jóllét közti kapcsolat megértését. Elsôként az, hogy bár a pozitív testkép egy összetett jelenség, a különbözô dimenziói között minimális a konceptuális átfedés. Tovább nehezíti a komplex összefüggések megértését, hogy a kutatások túlnyomó többsége tipikusan egy tényezôre koncentrál. Ezek közül különösen a test értéklésére vonatkozó faktorok kerülnek elôtérbe, miközben a pozitív testkép más vonatkozásait kevésbé vizsgálják.

Több szerzô hívta fel a figyelmet arra is, hogy a jóllétet és a testképet közösen vizsgáló kutatások többnyire a hedonikus jóllétre koncentrálnak, ami elsôsorban az érzelmi dimenziót hangsúlyozza (boldogság, pozitív énkép, pozitív érzelmek) (Swami, Weis, Barron, és Furnham, 2018). Egyre gyakrabban jelenik meg azonban az igény, hogy a test és a szubjektív jóllét kapcsolatainak megértése érdekében szükség lenne a háromdimenziós well-being-szemléletre, melyben egyszerre tud megjelenni a hedonikus (érzelmi, szubjektív), az eudaimonikus (önaktualizáló, pszichológiai, egzisztenciális) jóllét és a társas térben való jó funkcionálás (Hefferon, Ashfield, Waters és Synard, 2017). Ez a holisztikus, az általános pozitív orientációt (Capara, 2018) is jobban képviselô modell segíthetne megérteni azt is, hogy a pozitív testképnek milyen szerepe lehet az önmegvalósításban, illetve a társas funkcionálásban. Ez különösen fontos manapság, amikor a személyes identitás építésének és a teljesítmény bemutatásának 
egyik fố terepe a közösségi média, ahol az önmegmutatás és a személyes információk megosztása igen gyakran vizuális üzenetek által történik, annak minden bonyolult öszszefüggésével a testkép és az énkép vonatkozásában.

\section{A POZITÍV TESTKÉP HATÁRAI: A TESTPOZITÍV MOZGALMAK DILEMMÁI}

A pozitív testképpel kapcsolatos diskurzus egyik fontos jellemzóje, hogy igen gyorsan szétterjedt, és nem csupán az akadémiai keretek közt fejlődik és termel újabb kérdéseket, dilemmákat, hanem a közbeszédnek és a populáris médiának is fontos témája lett. Ez egyfelól megerôsíti, hogy nem életidegen, csak a tudomány képviselói számára kijelölt, l'art pour l'art problémáról, hanem a mindennapi létezést több szinten is érintô kérdéskörrôl van szó. Továbbá, bizonyítja azt is, hogy a tudományos elméletek és a köznapi reprezentációk egymásra hatva, egy állandó, dinamikus körforgásban képezik talaját az újabb és újabb koncepcióknak. A pozitív testkép szempontjából mindezt a testpozitív mozgalmak példáján keresztül mutatom be, felvillantva mindazokat a dilemmákat, melyek éles fénnyel világítják meg a kérdést, hogy mit jelent a „pozitivitás” - nem csupán a testképpel és az egészséggel kapcsolatban, hanem a pozitív pszichológia általános fogalmi keretrendszere szempontjából.

A szépségideállal és a társadalom által elvárt, normatív megjelenéssel kapcsolatban már a 19. század vége óta megjelentek tiltakozó mozgalmak, melyek általában a feminista irányzat különbözô hullámaihoz kapcsolódtak (Butler, 1993). Az utóbbi évek új fejleménye, hogy a mozgalom túllépett a feminista retorikán, és „testpozitivitás” (body positivity) elnevezéssel erôteljes civil fórummá és aktivizmussá nôtte ki magát, különösen a közösségi média segítségével.

Különösen erôs lendületet adott ennek az irányzatnak, hogy 2012 óta erôteljesen jelen van a testpozitív mozgalom az Instagramon is. Elsôsorban a „nem-normatív testet” hirdetố nôk használják a platformot, szelfiket közölve, hogy megkérdôjelezzék a domináns ideálokat például a sima bôrrel, a testalkattal vagy a testváladékok elutasításával kapcsolatban. A média is sokszor melléjük állt, és esetenként hôsként mutatta be azokat a nôket, akik például feltárták az evészavarukat, visszaszorították a testi tulajdonságokat stigmatizáló megszólalókat, megkérdôjelezték a „bikinire alkalmas test” mítoszát és a szülés utáni tökéletes testtel kapcsolatos elvárásokat. 2012-ben a feminista plus size modell, Tess Holiday alapította meg az @effyourbeutystangards Instagramfiókot, ahol elindította a kampányt, melyben felszólította a nóket, hogy akkor is szeressék a testüket, ha nagyobb, mint 10-es méretû. Tess Holiday mára a legismertebb „body positive” aktivista, 1,3 millió követôvel. 2015-ben a People Magazine címlapjára került, elsôként a 20-asnál nagyobb méretû modellek közül. Az amerikai Penningtons cégnél saját ruhamárkája is megjelent.

A testpozitív mozgalom számos formát és alakot öltött az utóbbi években. Alapvetô célja, hogy megkérdôjelezze a testtel kapcsolatos irreális ideálokat, és erôsítse az önelfogadást és az önértékelést az egyén énképének javítása által, továbbá segítsen elérni az önszeretetet (Szkiba, 2016). A mozgalom hangsúlyozza, hogy minden olyan egyént támogat, aki kívül esik a szépségnormákon. Ebben az önmeghatározásban igen erôs 
az áthallás a pozitív testkép koncepcióval - szinte azonosak a célkitûzések. Tovább erôsödik ez a benyomás, ha elolvassuk a részletesebb definíciót: „A testpozitivitás körébe tartozik minden olyan képi vagy verbális üzenet, amely megkérdőjelezi a test szépségideálok szerinti, domináns szemléleti keretét, és támogatja a megélt testi tapasztalatokat és a testkép kontrollját. A testpozitivitás magában foglal minden olyan egyéni vagy mozgalmi tevékenységet, amely a testtel kapcsolatos normák létrehozása és a társadalmi hatások ellen lép fel, és helyettük mindenféle alakú, méretú és megjelenésú test szeretetét és elfogadását támogatja, ideértve a zsírpárnákat, horpadásokat, cellulitiszt, pattanást, szônös testrészeket, vérzô testeket, kövér testeket, sovány testeket és fogyatékos testeket." (Cwynar-Horta, 2016, 37.)

A testpozitív mozgalmak egyik fô fókusza továbbra is a túlsúly és a nagyobb testméret megbélyegzése elleni harc, de idetartozik például a borotválkozás elutasítása, vagy az is, hogy bizonyos médiacsatornák nem fogadnak el retusált képeket, továbbá hogy a terhesség utáni alakváltozásokat ne tekintsék esztétikai kérdésnek a nôk (Money, 2017). De a mozgalom bizonyos képviselôi akár olyan szélsôséges álláspontok kialakításáig is elmehetnek, mint hogy a testkép már nem is fontos az egyén öndefiníciójában (Murray, 2007).

A mozgalom legfôbb összekötői a hashtagek. A legnépszerúbb ezek közül a \#plussize\#, ezt több millió nô használja, megmutatva az idealizálttól eltérô méretû testét. Fitnesz és jóga témában is egyre több a plus size kínálat (Impett, Daubenmier és Hirschman, 2006), ami egyfelôl nagyon pozitív hatású a testelfogadás és a pozitív testkép fejlesztése szempontjából, és facilitálja, hogy a szépségideáltól eltérô külsôvel is részt lehet és részt is kell venni sporttevékenységekben, azonban a képek által azt is sugallhatja, hogy nem kell törôdni az elhízással, mintegy azt mondván, hogy a szépség egyszersmind egészséget is jelent.

A testpozitív mozgalmak hashtagjei azonban inkább az egészség pozitív, holisztikus koncepcióját hirdetik, így például: „A gyúlöletet csökkentsd, ne a testsúlyodat!” (\#Losehatenotweight\#), vagy „Egészséget minden méretben” (\#Health at Every Size\#). Olyan site-ok jelennek meg, ahol saját élményeket és történeteket osztanak meg azzal kapcsolatban, hogy milyen elôítéletes módon kezelték, vagy egyenesen félrekezelték óket az egészségügyben a testsúlyuk miatt (pl. \#Diagnosisfat\#).

A közösségi médiafelületeken számos, az elhízottakkal kapcsolatos elôítélet ellen lázadó megnyilvánulással találkozhatunk, ahol az egyenlố bánásmódot követelik, és fellépnek a megkülönböztetés minden formája ellen, legyen az iskolai zaklatás vagy munkahelyi diszkrimináció: \#effyourbodystandards\# vagy \#riotsnotdiets\#, \#fightfatphobia\# (Phelps, 2016). A hashtagek nyelve segít erôteljesen ráirányítani a figyelmet arra, hogy a túlsúly nem egyenlő a lustasággal, felelôtlenséggel, morális gyengeséggel (Tomiyama és mtsai, 2018). Idekapcsolódik a vizuális nyelv átalakítása is, így megjelent a testpozitív múvészet, de akár kifestôkönyvek is kaphatók ilyen témában.

A testpozitív retorika a túlsúlyt gyakran az alkoholizmushoz és dohányzáshoz hasonlóan addikcióként állítja be, és a fogyasztói társadalmat, valamint az élelmiszeripart vádolja - az érintetteket áldozatként, a túlsúlyt pedig emberi jogként tünteti fel. Ezen a ponton ismét utalni kell arra a dilemmára, hogy a túlsúly elfogadása nem jelenti-e egyúttal az azzal járó egészségügyi rizikók elfogadását is. Különösen abból a szempontból gyakorlati jelentôségú ez a kérdés, hogy az utóbbi idôben olyan népszerú ismeret- 
terjesztô könyv is megjelent, amely aggasztó módon kifejezetten azt propagálja, hogy az elhízás nem jár egészségkockázattal (Bacon, 2010). A kritikusok viszont az egyén felelősségének tekintik a túlsúlyt, és azzal érvelnek, hogy nem a társadalom többi részének kellene megfizetni az ebbôl adódó egészségügyi többletkiadásokat, és felhívják a figyelmet arra a veszélyre, hogy a testpozitív mozgalom a túlzott önelfogadás propagálásával az egészségmegôrzô viselkedés leértékelését és a rizikóviselkedés erôsödését hozhatja magával (Robinson, Haynes, Sutin és Daly, 2017; Muttarak, 2018).

Egyre több tanulmány foglalkozik azzal is, hogy miként üzletiesedett el a mozgalom, és miként vált hirdetési platformmá az Instagram, ahol a testpozitivitás legfơbb üzenetei megjelennek (Cwynar-Horta, 2016). Bizonyos kritikusok szerint a cégek érdeke az, hogy minél szélesebb vásárlóréteget tudjanak elérni, ezért használják fel az Instagram-influenszereket (plus size modelleket, makeupmentességet hirdetôket stb.). A hatalmas Instagram-tömeg ugyanis valóban jól jött a divatiparnak, hiszen így pontosan meg tudják célozni a reklámokkal a felhasználókat. Mostanra néhány divatmárka „testpozitívnak” hirdeti magát csupán azért, mert betesz makeup nélküli vagy plus size modelleket is a kollekcióba. PR-cégek keresik fel az influenszereket, és segítenek nekik a saját profiljuk megalkotásában és persze abban, hogy az adott márkához tartozó termékekben mutatkozzanak. Tehát amit a nyilvánosság lát ezekból az influenszerekbôl, az gyakran egy jól megkonstruált (sok esetben manipulált) „identitás-brand”. Az influenszerek pedig innentôl kezdve - nem feltétlenül tudatosan - azon dolgoznak, hogy megfeleljenek ennek az identitásnak. Másfelôl pozitív példákat is találhatunk, ahol a kozmetikai és szépségipar képviselôi éppen a testpozitív mozgalmakhoz kapcsolódva, és a pozitív pszichológia tudományos alapjaira támaszkodva hoznak létre színvonalas kampányokat és ismeretterjesztố támogató programokat a test elfogadásával kapcsolatban. Ilyen például a Dove kozmetikai márka Önbizalom Programja, amely számos országban elérhetô, és a közelmúltban Magyarországon is megjelent (https:// www.dove.com/hu/dove-self-esteem-project.html).

\section{KITEKINTÉS: A POZITÍV TESTKÉP KUTATÁSÁNAK TOVÁBBI KÉRDÉSEI}

Amint a fentiekben egy kis bepillantást kaptunk a folyamatba, láthattuk, hogy az utóbbi közel két évtizedben jelentôs elmozdulás történt a testképzavarok kutatásának hagyományos hangsúlyától a pozitív testkép jellemzőinek minél részletesebb feltárásán és a testkép általános vonatkozásainak leírásán át egészen a testpozitív mozgalmakig, melyek egyfelôl popularizálják, másfelôl kiélesítik a pozitív testképpel kapcsolatos dilemmákat. A pozitív testkép kutatása magával hozza, hogy a testképpel kapcsolatos ismeretek és intervenciók bôvítése által miként javítható a pszichológiai jóllét és az általános egészség, illetve miként csökkenthetô a stressz. Mostanra a kutatások meglehetôsen szilárd empirikus alapokra támaszkodnak, és elkezdték specifikusan vizsgálni az életkori, nemi és kulturális vonatkozásokat, továbbá a testkép pozitív fejlesztésének a kérdését.

Meggyôző bizonyítékok állnak rendelkezésre arra vonatkozóan, hogy a testértékelés további variációkat jelez a szubjektív jólléttel kapcsolatban a testtel való elégedetlenség kontrollálása után. Ez hozzásegít annak megértéséhez, hogy a pozitív és negatív 
testkép független dimenziók, viszont annak érdekében, hogy ez a tudás megerôsödjön és a gyakorlati alkalmazás alapjává, intervenciós programok kiindulópontjává váljon, még sok további vizsgálatra van szükség. Erre hívják fel a figyelmet többek között a testpozitív mozgalmak dilemmái és ellentmondásai is, felmutatva a pozitív pszichológia számára, hogy a „pozitivitás” és „pozitív orientáció” koncepciók jól beágyazhatók a testtel való foglalkozás mindennapi kereteibe, és ott akár a tudatosodás, a kontroll és az autonómia eszközei is lehetnek. Másfelôl viszont ezek az eszközök - ha viszszaélnek velük, vagy nem jól használják ôket -, éppen a test jóllétét és egészségét is veszélyeztethetik.

További fontos fejlesztendô és kihívásokkal teli terület a mérôeszközök kérdése. Korábban, amikor elsôsorban a negatív testképpel foglalkoztak, számos mérôeszközt és konstrukciót használtak, amelyeket egymással kiválthatónak gondoltak az irodalomban, holott nem voltak azok. Szükség lenne a pozitív testkép vizsgálatakor is egy egységes mérôeszközre, de igazából maga a pozitív testkép koncepciója sem egységes még - amint láthattuk, az összetevôk nincsenek pontosan meghatározva. Mivel a pozitívtestkép-irodalomban a legtöbb helyen a Testértékelés Skálát (BAS) használják az egyik fô mérôeszközként, ez módot adhat egy általános koncepció létrehozására, továbbá arra is, hogy a pozitiv és a negativ testkép kapcsolatát jobban lássuk. További kérdés az is, hogy a pozitív testkép stabil vonás vagy szituációs változó-e.

Végezetül pedig, a talán legnagyobb kihívás a fejlődési dimenzióban rejlik, azaz abban, hogy miként lehet olyan elméleteket és gyakorlati alkalmazásokat kifejleszteni, melyek igazodni tudnak a felhasználók életkorához. Egyre több kutatást végeznek gyerekek körében a (negatív) testképpel kapcsolatban, ezt ki kellene terjeszteni a pozitív testképre is (Halliwell, Jarman, Tylka és Slater, 2017). Ezáltal kapcsolódhatna a kutatás és az alkalmazás is ahhoz az alapelvhez, hogy maga a pozitív testkép egy növekedést, fejlốdést is magában foglaló konstrukció, tehát nem lehet statikus változóként kezelni, hanem rugalmasan, a folyamatos változás nyitottságával lehet csak kutatni, és továbbfejleszteni.

\section{IRODALOM}

Avalos, L. C, Tylka, T. L, \& Wood-Barcalow, N. (2005). The Body Appreciation Scale: Development and psychometric evaluation. Body Image, 2, 285-297.

Bacon, L. (2010). Health at Every Size: The Surprising Truth about Your Weight. Dallas: BenBella Books.

Béres, A., Czeglédi, E. \& Babusa, B. (2013). A testedzésfüggőség és a testkép vizsgálata fitneszedzést végzố nốk körében. Mentálhigiéné és Pszichoszomatika, 14(2), 91-114.

Butler, J. (1993). Bodies That Matter. New York: Routledge.

Caprara, G. V., Alessandri, G. \& Caprara, M. (2019). Associations of positive orientation with health and psychosocial adaptation: A review of findings and perspectives. Asian Journal of Social Psychology, 22(2), 126-132.

Cash, T. F., \& Fleming, E. C. (2002). The impact of body image experiences: Development of the Body Image Quality of Life Inventory. International Journal of Eating Disorders, 31, 455-460.

Cash, T. F. (2004). Body image: Past, present and future. Body Image, 1, 1-5. 
Cash, T. F., Jakatdar, T. A., \& Williams, E. F. (2004). The Body Image Quality of Life Inventory: Further validation with college men and women. Body Image, 1, 279-287.

Cash, T. F. (2008). The body image workbook. 2nd edition. Oakland, CA: New Harbinger.

Csabai, M. \& Erôs, F. (2000). Testhatárok és énhatárok. Az identitás változó keretei. Budapest: Jószöveg Múhely Kiadó.

Cwynar-Horta, J. (2016). The Commodification of the Body Positive Movement on Instagram Stream: Culture/Politics/Technology, 8(2), 36-56.

Favazza, A. (2011). Bodies Under Siege: Self-mutilation, Nonsuicidal Self-injury, and Body Modification in Culture and Psychiatry. Baltimore: The Johns Hopkins University Press.

Frank, A. W. (1998). From dysappearance to hyperappearance: Sliding boundaries of illness and bodies. In H. Stam (Ed), The body and psychology (pp. 205-232). London: Sage Publications.

Gillen, M. M. (2015). Associations between positive body image and indicators of men's and women's mental and physical health. Body Image, 13, 67-74.

Halliwell, E. (2015). Future directions for positive body image research. Body Image, 14, 177-189.

Halliwell, E., Jarman, H., Tylka, T. \& Slater, A. (2017). Adapting the Body Appreciation Scale-2 for Children: A psychometric analysis of the BAS-2C. Body Image, 21, 97-102.

Hefferon, K. (2013). Positive Psychology and the Body: A somatopsychic side to flourishing. London: Open University Press.

Hefferon, K. (2015). The Role of Embodiment in Optimal Functioning. In S. Joseph (Ed): Positive Psychology in Practice: Promoting Human Flourishing in Work, Health, Education, and Everyday Life. New Jersey: John Wiley \& Sons Inc., 791-805.

Hefferon, K., Ashfield, A., Waters, L., \& Synard, J. (2017). Understanding optimal human functioning-The 'call for qual' in exploring human flourishing and well-being. The Journal of Positive Psychology, 12(3), 211-219.

Impett, E. A., Daubenmier, J. J., \& Hirschman, A. L. (2006). Minding the body: Yoga, embodiment, and well-being. Sexuality Research E Social Policy, 3(4), 39-48.

Menzel, J. E., \& Levine, M. P. (2011). Embodying experiences and the promotion of positive body image: The example of competitive athletics. In R. M. Calogero, S. Tantleff-Dunn \& J. K. Thompson (Eds), Self-objectification in women: Causes, consequences, and counteractions (pp. 163-186). Washington, DC: American Psychological Association.

Money, C. (2017). Do the clothes make the (fat) woman: the good and the bad of the plus-size clothing industry. Siegel Institute Ethics Research Scholars. Volume I. The Ethics of Clothing. 1-21. Article 1. Letöltve: 2019. 09. 17-én: https://digitalcommons.kennesaw.edu/siers/ voll/iss $1 / 1$

Murray, S. (2007). Corporeal Knowledges and Deviant Bodies: Perceiving the Fat Body. Social Semiotics, 17(3), 361-373.

Muttarak, R. (2018). Normalization of Plus Size and the Danger of Unseen Overweight and Obesity in England. Obesity, 26(7), 1125-1129.

Obál, A., Hamvai, Cs. \& Pikó, B. (2019): A testbecsülést befolyásoló tényezók vizsgálata serdülô lányok körében. Egészségfejlesztés, 60(2), 6-17.

Oláh, A. (2019). Positivity is an up-to-date predictor of well-functioning instead of a eudaemon. Asian Journal of Social Psychology, 22, 143-145.

Orbach, S. (2009). Bodies. London: Penguin Books.

Phelps, K. (2016). Taking Up Digital Space: Power and Potentialities of Fatness on Social Media. Letöltve: 2019. 09. 26-án: http://www.asanet.org/news-events/asa-news/taking-digital-s pace-power-and-potentialities-fatness-social-media 
Piran, N., \& Teall, T. L. (2012). The developmental theory of embodiment. In McVey, G., Levine, M. P. \& Piran, N. \& Ferguson, H. B. (Eds), Preventing eating-relatedand weight-related disorders: Collaborative research, advocacy, and policy change (pp. 171-199). Waterloo, ON: Wilfred Laurier Press.

Robinson, E., Haynes, A., Sutin, A. R. \& Daly, M. (2017). Telling people they are overweight: helpful, harmful or beside the point? International Journal of Obesity, 41, 1160-1161.

Schilder, P. (1935). The Image and the Appearance of the Human Body; Studies in Constructive Energies of the Psyche. London: Paul, Trench, Trubner.

Stice, E. (2001). A prospective test of the dual-pathway model of bulimic pathology: Mediating effects of dieting and negative affect. Journal of Abnormal Psychology, 110, 124-135.

Swami, V., \& Jaafar, J. L. (2012). Factor structure of the Body Appreciation Scale among Indonesian women and men: Further evidence of a two-factor solution in a non-Western population. Body Image, 9, 539-542.

Swami, V., Kannan, K., \& Furnham, A. (2012). Positive body image: Inter-ethnic and rural-urban differences among an indigenous sample from Malaysian Borneo. International Journal of Social Psychiatry, 58, 568-576.

Swami, V., Weis, L., Barron, D. \& Furnham, A. (2018). Positive Body Image is Positively Associated with Hedonic (Emotional) and Eudaimonic (Psychological and Social) Well-Being in British Adults. The Journal of Social Psychology, 158(5), 541-552.

Szkiba, Zs. (2016). Fogadd el magad. Pozitív testkép, egészséges önbizalom. Budapest: Libri.

Tiggemann, M., \& McCourt, A (2013). Body appreciation in adult women: Relationships with age and body satisfaction. Body Image, 10(4), 624-627.

Tomiyama, A. J., Carr, D., Granberg, E. M., Major, B., Robinson, E., Sutin, A. R., \& Brewis, A. (2018). How and why weight stigma drives the obesity 'epidemic' and harms health. $B M C$ Medicine, 16(1). https://doi.org/10.1186/s12916-018-1116-5

Tylka, T. L. (2011). Positive psychology perspectives on body image. In Cash, T. F. \& Smolak, L. (Eds): Body image: A handbook of science, practice, and prevention. 2nd edition. New York: Guilford Press, 56-64.

Tylka, T. L., \& Wood-Barcalow, N. L. (2015a). The body appreciation scale-2: Item refinement and psychometric evaluation. Body Image, 12, 53-67.

Tylka, T. L., \& Wood-Barcalow, N. L. (2015b). What is and what is not positive body image? Conceptual foundations and construct definition. Body Image, 14, 118-129.

Williams, E. F., Cash, T. F., \& Santos, M. T. (2004). Positive and negative body image: Precursors, correlates, and consequences. Paper presented at the $38^{\text {th }}$ Annual Meeting of the Association for Advancement of Behavior Therapy, New Orleans, LA.

Wood-Barcalow, N. L., Tylka, T. L. \& Augustus-Horvath, C. L. (2010). „But I like my body”: Positive body image characteristics and a holistic model for young-adult women. Body Image, 7, 106-116. 


\title{
FROM THE CHALLENGES OF SELF-ACCEPTANCE TO BODY POSITIVE MOVEMENTS: BODY IMAGE IN POSITIVE PSYCHOLOGY
}

\author{
CSABAI, MÁRTA
}

Despite body image and self-image are basic determinants of our connections to ourselves and to the world, the earlier studies had focused mainly on negative body image. The positive body image, as an independent construct appeared with a relative delay also in positive psychology. The researches in recent years have proved that positive body image is not the mirroring of negative body image, but a unique and independent dimension. It is related to several factors influencing subjective well-being and other factors related to positive orientation. One of the emerging components is self-acceptance. The paper gives a summary about the international development of the body image concept and also explains how the positive body image construct represents the basic principle of positive psychology, that positivity is not a mere absence of disfunction or negative states. The questions and dilemmas of positive body image, related to control and autonomy, are vividly highlighted by the body positivity movement. This movement is a suitable case example to help us to think over some of the most important contemporary challenges of positive psychology both from the perspectives of theory and practice.

Keywords: positive body image, self-acceptance, subjective well-being, body positive movement

A cikk a Creative Commons Attribution 4.0 International License (https://creativecommons. org/licenses/by/4.0) feltételei szerint publikált Open Access közlemény, melynek szellemében a cikk bármilyen médiumban szabadon felhasználható, megosztható és újraközölhetô, feltéve, hogy az eredeti szerzô és a közlés helye, illetve a CC License linkje és az esetlegesen végrehajtott módosítások feltüntetésre kerülnek. (SID_1) 